\title{
OPTIMIZATION OF LENDING SYSTEM IN THE CONDITIONS OF GLOBAL PANDEMIC IN GEORGIA
}

\author{
Kakhniashvili Natia, Doctor of Business Administration, Invited Associate Professor of Tbilisi State \\ University, Tbilisi, Georgia
}

\section{DOI: https://doi.org/10.31435/rsglobal_conf/25062021/7602}

\begin{abstract}
The banking sector is the backbone of the country's economy, where ongoing processes significantly determine the financial stability of the country. In the modern world, this topic does not lose its relevance, moreover, it is becoming more and more the center of attention.

As it is known, Georgia is a developing country, where the largest share of the financial sector belongs to the banking sector. Community life, including primarily the business sector, which significantly depends on the effective functioning of the credit sector.

The article is dedicated to modern trends, first of all the Covid-19 pandemic the biggest challenge of the 21 st century, because of it the banking sector faced the biggest challenges and completely changed the credit environment. The article reflects the reality of whether the Georgian banking sector is ready to deal with various types of financial crises in the changing environment.
\end{abstract}

Keywords: Bank, credit, currency, restructuring, pandemic, optimization.

Introduction. The credit system is an essential attribute of a developed market economy, the establishment and successful management of which plays a crucial role in the process of achieving economic sustainability. International experience has shown that quite a large part of the world's population enjoys financial intermediaries, which in turn ensure that existing financial needs are met in a variety of ways. This circumstance applies to both developed and developing countries. Due to its specificity, the credit system affects virtually any field, taking into account different circumstances formulates their directions and strategies. In a modern global world where economic crises are intensifying, at the forefront are the issues of achieving efficient functioning of the banking credit system. Each of us lives in a world where financial institutions and the functions they fulfil play a major role in our lives. Credit can be presented as one of the aids to achieve self-realization, that is why there is an increased interest in this field.

A research aim is to consider the current processes in the field of credit in the context of the national economy and also analysis of various environmental factors, which in turn affect the above mentioned system, such as the digital economy stimulation processes, transformation of needs in the field of finance, etc. It is a priority to discuss extensively the various indirect circumstances, which significantly change the banking conditions, for example, like the pandemic today, which created as a financial crisis in the world, it also created various opportunities, which must be seen and analyzed for further progress.

Methods used in the study. The works of Georgian and foreign economists are used in the research process, various statistical databases as well as internet publications and articles related to this issue.

Because of Covid Pandemic the world economy has faced a historic challenge. The business world has been trying to cope with the pandemic crisis for more than a year. The economies of different countries have been able to fight the problem in different ways. The banking sector is no exception, vice versa it is an area where the effects of the pandemic have been quite strongly reflected. The spread of the pandemic involved different stages and consequently different degrees, considering this the state had to introduce some strict regulations because it protected the health of the citizens. These regulations were complex, which included restricting movement at various scales, introducing curfew hours, restricting the operation of certain businesses, and so on. All this had a negative impact on the effective functioning of the economy and in this case the credit sector in particular. Although the activities of the banking sector were not directly restricted, the degree of their effectiveness is directly related to the business groups or individuals whose activity has been suspended or slowed down.

The government and the National Bank have developed various measures to reduce the negative effects of the pandemic, which were aimed at resolving various critical issues. The purpose of 
these measures was to promote lending, Provide financial support to customers, reduce supervisory burden, etc. The effects of pandemics are closely related, especially in the banking sector because here any restrictions that applied to any particular area would directly affect the profitability of the banking sector. A short list of initial changes looks like this:

- Reserve policy was temporarily changed and grace period loans were encouraged;

- On-site inspection of supervised entities was temporarily suspended, the method of real estate evaluation has also changed;

- Signing a \$200 million limit swap agreement with the European Bank for Reconstruction and Development (EBRD), which enables them to further increase private sector funding in local currency;

- At the initial stage, the refinancing rate was reduced by 1 mark by 1 August and became $8 \%$, today this mark reaches $9.5 \%$;

- 80 percent funding for hotels with less than 20 million turnover within 6 months;

- Subsidizing 4 percent a portion of the nominal interest rate for encouraging mortgages.

In addition to the above measures, the National Bank has carried out a number of measures with the government, at each stage of the pandemic, for example, a state guarantee on mortgages issued on $01 / 06 / 20$ - 01/01/2021, etc. Of course, these measures had relevant consequences for example, $36 \%$ of loans issued between July and September 2020 were mortgages, whose percentage was subsidized by the state.

By the end of 2020, the quality of the portfolio has deteriorated significantly compared to the previous year. Taking into account the expected risks, the banks together have reserved GEL 1.1 billion in the reserve for possible loan losses, that is, they recorded beforehand the expected loss in the balance sheet.

According to the National Bank, 8.4 percent of bank loans are inactive, which is twice the rate compared to the previous year, moreover, this process is still going to a negative direction. Non-performing loans are divided into categories and segments. It is important to separate them, as each category growth can have a different impact, these are: Non-standard loans- 2.2 billion GEL; Doubtful loans - 484 million GEL; Hopeless - 489 million GEL. By segments: Inactive corporate loans - Corp. -7.44\% of credits; Inactive small and medium business loans $-9.75 \%$; Individual loans $-9.3 \%$ are inactive.

Considering the slowdown in economic life and because there were fewer credit losses, commercial banks have taken unprecedented measures to restructure loans, which led to the restructuring of $20 \%$ of the loan portfolio by the end of 2020 . This data exceeds the 2019 data by $15 \%$. Most of the restructuring took place on foreign currency loans, which accounted for $25 \%$ of the portfolio of these types of loans. Despite the increased credit risks, the banking sector started 2021 with a profit and saw a total profit of GEL 584 in the first 4 months. The data was divided by percentage as follows: January - 19\%, February - 23\%, March - 28\%, April - 30\%. Also, the share of non-performing loans in mortgage loans has increased. Where we have the following data: Inactive national mortgage loans - 4\%; Mortgage loans in foreign currency $-11 \%$. The data show a growing trend of net profit by months, which allows us to make an optimistic forecast.

In total, the banks received GEL 1.82 billion in revenue in the first 4 months, of which GEL 1.47 was interest, of which 763 million was interest paid by individuals and 531 was interest paid by legal entities. Revenue from fines and conversion transactions totaled $\$ 355$ million. As for the expenses, the banks generated a profit of 640 million GEL in these four months, including 241 million GEL on salaries.

In the conditions of the pandemic, commercial banks were not only thinking about improving their financial performance, but also trying to act in order to improve the quality of health care. A large portion of operations shifted to remote services, which drastically reduced traffic and ultimately posed a critical issue for consumer health. During the necessary visit, mechanisms were set up to protect the health of consumers, in particular to protect the distance by using appropriate markings. Also increase the limits for payment without a password at the terminal and withdraw money from ATMs, as well as change the terms of pension enrollment, which hindered their uniform mobility, etc.

Conclusions. In today's rapidly changing global environment, economic sustainability is an important determinant of a developed country. In turn, economic strength is conditioned by the financial sector, and most of all the efficient functioning of the banking sector. The experience gained 
in the financial sector allows the representatives of the modern banking sector to create and offer customized products to the market.

Properly managed credit policy is the basis for risk reduction, which in turn is an important component in the process of maximizing the profitability of the banking sector.

Based on the issues discussed above, we can conclude that properly selected credit policy plays a major role in the successful functioning of the banking sector. Which enables them to maintain a high degree of functionality in changing environments. This is all well seen in pandemic banking, where despite the challenges yet it was slowly adapting to the existing environment, minimize damage at the initial stage and finally profitable operation.

\section{REFERENCES}

1. Mghebrishvili V, Problems between Consumers and Banks, Tb., 2021. Retrieved from https://bm.ge/ka/article/ori-problema-rac-momxmarebelsa-da-bankebs-shoris-arsebobs---giorgikepuladzis-mosazreba/80561/

2. Shalamberidze Kh. "Banking Trends, Pandemic and Transformation of Banking Products", Tbilisi, 2020.

3. "National Bank of Georgia", Financial Stability Report, Tb., 2020.

4. „National Bank of Georgia." Emergency measures of the National Bank of Georgia in connection with COVID-19, Tbilisi, 2021.

5. A. Saunders and M. M. Cornett, Financial Institutions Management: A Risk Management Approach, 2010.

6. E. Altman, "ZETA analysis: a new model to identify bankruptcy risk of corporations," Journal of Banking and Finance, NY, 2010.

7. Florian Heider, Farzad Saidi, Glenn Schepens, Banks and negative interest rates, Frankfurt, 2021.

8. E. Altman, Revisiting Credit Scoring Models in a Basel 2 Environment., London: Risk Books, 2002. 